\title{
The Concept of Zero Waste in the Context of Supporting Environmental Protection by Consumers
}

\author{
Małgorzata Bogusz ${ }^{1, *(\mathbb{D}}$, Renata Matysik-Pejas ${ }^{1, * \mathbb{D}}$, Andrzej Krasnodębski $^{1}$ and Paweł Dziekański $^{2} \mathbb{D}$ \\ 1 Department of Management and Economics of Enterprises, University of Agriculture in Krakow, \\ Mickiewicza 21, 31-120 Kraków, Poland; andrzej.krasnodebski@urk.edu.pl \\ 2 Department of Economics and Finance, Jan Kochanowski University in Kielce, Uniwersytecka 15 Str., \\ 25-406 Kielce, Poland; pawel.dziekanski@ujk.edu.pl \\ * Correspondence: malgorzata.bogusz@urk.edu.pl (M.B.); renata.matysik-pejas@urk.edu.pl (R.M.-P.)
}

Citation: Bogusz, M.;

Matysik-Pejas, R.; Krasnodębski, A.; Dziekański, P. The Concept of Zero Waste in the Context of Supporting Environmental Protection by Consumers. Energies 2021, 14, 5964. https://doi.org/10.3390/en14185964

Academic Editor: David Borge-Diez

Received: 26 August 2021

Accepted: 17 September 2021

Published: 20 September 2021

Publisher's Note: MDPI stays neutral with regard to jurisdictional claims in published maps and institutional affiliations.

Copyright: (c) 2021 by the authors. Licensee MDPI, Basel, Switzerland. This article is an open access article distributed under the terms and conditions of the Creative Commons Attribution (CC BY) license (https:/ / creativecommons.org/licenses/by/ $4.0 /)$.

\begin{abstract}
Zero waste according to the Zero Waste International Alliance is an ethical, economical, effective and forward-thinking concept whereby people can change their lifestyles and habits to one that mimics natural cycles, where all discarded materials are designed to become resources that can benefit others. The aim of the study was to determine the knowledge of the Zero Waste problem (subject of the study) by respondents in selected Central and Eastern European countries, including Poland, Slovakia (EU countries) and Ukraine (EU associated country), as well as to verify whether the Zero Waste rules are known and implemented in sustainable activities of residents in the studied countries. The research was carried out using the CAWI method. The research tool was a structured questionnaire. The analysis of data from the countries covered by the study showed a significant relationship between the basic elements in the daily functioning of households related to the protection of the environment through responsible consumption, reuse and recovery of selected products, packaging and materials and food and the concept of Zero Waste. Research has shown that respondents consciously identify these activities with Zero Waste. According to the authors, the results of the research are the basis for public discussion at the European and global level in the field of creating legal regulations and educational programs in the context of waste management.
\end{abstract}

Keywords: zero waste; sustainable development; circular economy; waste management; CentralEast Europe

\section{Introduction}

Environmental responsibility is part of a broad philosophy of the functioning of the modern economy, namely the so-called sustainable development. The starting point of the discussion on sustainable development was the observation in the 1970s and 1980s that mankind poses a threat to the basis of its own life from overexploitation of natural resources. Although there have been isolated voices in this regard over the years, it was not until the first United Nations conference on environmental protection was held in Stockholm in 1972 that the issue was raised. The awareness of environmental degradation led to an agreement in 1992 at the United Nations conference in Rio de Janeiro on new guidelines for development, which were collectively known as sustainable development. The consequence of this conference was the adoption of Agenda 21 as the global strategy for sustainable development and the recognition of the new model by all international organizations. The EU, on the other hand, included sustainable development in its founding treaty [1]. This concept is based primarily on the sustainable improvement of the quality of life of present and future generations through proper management of economic, human and natural capital [2]. This approach is based on three pillars, which are society, economy and environment. It poses a significant cognitive and practical problem, because it can be understood and interpreted in many ways, and the implemented policies and development strategies may contain different content and scope. This concept is gaining popularity, so 
sometimes it is difficult to assess whether we are dealing with a real scientific category or just a marketing effort. In this situation, it is important to look at sustainable development from the point of view of entities that apply economic instruments for its support in the given economic and social reality. Creating sustainable development is connected with the ecological awareness of society, an important element of which is a sense of threat to the nature surrounding humanity and social belonging and responsibility [3]. In recent years, the concern about the state of the environment has been observed, so the formation of an appropriate attitude of society to the environment becomes a significant goal, as well as the need to solve many problems occurring in both the economic and social areas [4]. Industrialization and globalization make the concept of sustainable development increasingly important. This is why the UN's 2030 Agenda for Sustainable Development, adopted by world leaders in 2015, provides a new global framework for sustainable development and sets out 17 Sustainable Development Goals [5]. The Agenda expresses commitments to eradicate poverty and achieve sustainable development worldwide by 2030 so that no one is left behind [6]. The twelfth sustainable development goal concerns responsible consumption and production. It calls for a significant reduction in waste generation by 2030 through prevention, reduction, recycling and reuse [5]. Waste, including municipal waste, is a macroeconomic problem that is an integral part of population growth and urbanization [7], as well as the processes of production and consumption, and therefore the creation and distribution of GDP [8]. At the same time, the growing amount of waste shows the inefficiency of modern societies and the misallocation of resources [9].

In 2019, the amount of municipal waste in European Union countries was almost 225 million tons. This means that the average EU citizen generated $502 \mathrm{~kg}$ per year [10]. Municipal waste accounts for only about $10 \%$ of all waste generated, but the problem is its management and processing [11]. It is expected that by 2050 global municipal waste generation will increase to 3.4 billion cubic tonnes [12]. The generation of waste depletes natural resources, alters the climate (greenhouse gases) and generates an additional economic cost associated with its management [13]. Improper waste management negatively impacts human health and the environment through contamination of soil, water and air, and changes land use and landscape [11,14]. The natural environment is a complex element made up of interrelated factors. Changes and weakening of one of them affect the functioning of the entire environment. The natural environment has an impact on the quality of human life. It is subject to constant changes resulting from human activity. The negative impact of entities on the natural environment requires taking measures to limit the processes taking place in it (including waste reduction). The undertaken environmental strategies of local authorities more and more often include elements of the Zero Waste concept. The pursuit of waste minimization and high recycling rates is a major challenge in many countries today, also because it is in line with the concept of intergenerational equity, which is considered to be at the heart of sustainable development in its modern sense [15]. The idea of sustainable development (derived from the concept of eco-development, which postulated such a way of management that does not exceed the capabilities of the environment) [16] is a comprehensive response to the challenges of today's world. Sustainable development is an interdisciplinary issue encompassing broad groups of problems related to technology, ecology, economics, as well as politics or sociology and social conditions $[17,18]$. The point of sustainable development is to achieve synergy between its individual goals and areas. Waste management is most closely related to the environment, but also to economy and society [19]. To achieve the goals of sustainable economic growth, it is necessary to reduce negative environmental impacts by changing the way we produce and consume [20]. According to the principle of sustainable development, waste policy should aim to reduce the environmental and health impacts of waste and improve resource efficiency. It aims to reduce the amount of waste generated. However, if the generation of waste is unavoidable, the use of waste as a resource should be promoted, as well as promoting recycling and ensuring safe disposal. One of the EU's 
overarching objectives in relation to waste management is also to break the link between economic growth and waste generation [21].

Zero waste (ZW) according to the Zero Waste International Alliance [22] is an ethical, economical, effective and forward-thinking concept through which people can change their lifestyles and habits to mimic natural cycles, where all discarded materials are designed to become resources that others can use. This means abandoning the waste disposal approach in favor of resource management. The huge amount of waste and recycling problems in developing countries remain a big problem. There are major disruptions and conflicts caused by the garbage problem. ZW is a set of processes that aims to protect the environment from a much broader perspective than the commonly known hierarchy of ways to deal with waste. ZW rules communicate that the focus should be on resource efficiency and waste avoidance. ZW does not restrict the rational management of waste, but proposes to optimize the current recycling activities. It strives to create and apply new, innovative methods which are to minimize the amount of waste [23].

The aim of the study was to determine the knowledge of the Zero Waste problem (subject of the study) by respondents in selected Central and Eastern European countries, including Poland and Slovakia (EU countries) and Ukraine (EU associated country), as well as to verify whether the ZW rules are known and implemented in sustainable activities of residents in the studied countries.

This goal of the study was reinforced by the following research questions:

(1) What is the degree of knowledge of the concept of $\mathrm{ZW}$ among the respondents?

(2) What elements of the daily functioning of households are associated by the respondents with the principles of ZW?

(3) What goals, according to the respondents, are pursued by activities related to the ZW?

\section{Literature Review}

The term "zero waste" was used publicly in the first half of the 1970s by Paul Palmer, who used it in the name of the company he founded (Zero Waste Systems) [24]. Palmer's interest in waste reduction was influenced more by scientific and financial reasons than environmental ones. He noticed that companies were throwing away clean, often valuable chemicals that could be reused [25]. The organization that proposed the definition of the term ZW was the Zero Waste International Alliance. The first definition dates back to 2004, but the term was redefined twice more (in 2009 and 2018). The most recent definition of ZW to be a universal definition of the term says that $Z W$ is "The conservation of all resources by means of responsible production, consumption, reuse, and recovery of products, packaging, and materials without burning and with no discharges to land, water, or air that threaten the environment or human health" [26]. The term ZW spread first in the United States and then around the world. Today, ZW is a buzzword with many different meanings and multiple ways of impact as the concept continues to evolve [27]. ZW is an idea that encompasses a diversity of means, experiences and interpretations [28] emerging in the realms of industrial practice implementation, municipal practice and, also, among social activists and consumers.

In the context of industrial practice, $\mathrm{ZW}$ is the creation and application of innovative methods to minimize waste and conserve resources. $\mathrm{ZW}$ is a concept that encourages the redesign of products in such a way that, over the life cycle of the products, the raw materials from which they are made can be reused many times until the optimum level of consumption is reached. In this system, no materials are wasted but used as inputs, replacing the need to extract natural resources. According to this idea, waste is not sent to landfills or incinerated. Therefore, the concept of ZW fits into a closed loop economy, where resources are used instead of creating waste [29]. The concept of circularity has deep roots both historically and philosophically. The idea of closed circulation, cyclicity of processes occurring in nature, was defined already in antiquity. The consumption of raw materials began to exceed the possibility of their regeneration, thus the previous paradigms of management based on linearity (production-consumption-utilization) turned out to be 
harmful in a broad context. The holistic doctrine of the circular economy, which is based on reducing environmentally harmful waste but also on keeping raw materials in circulation as long as possible in order to offset the harmful effects of their production, has become the best response to this state of affairs [30]. CE has brought a systematic approach that incorporates environmental concerns into economic development. Moreover, $\mathrm{CE}$ has inspired alternative business models that allow the concept of sustainability to be understood as a state of balance of society's economic, environmental and social concerns [31]. Issues of ecology in economic development have achieved priority status in recent years. This has been highlighted in the concept of sustainable economic development, as well as in the idea of circular economy, which is a confirmation of the increasing knowledge of the impact of economic processes on the environment, as well as the awareness of the limitation of the resources used [32].

At the European Union level, actions have been taken in the field of sustainable development policy for years, starting from the Amsterdam Treaty, through the Lisbon Strategy and the Sustainable Development Strategy of 2001, to "the Europe 2020" Strategy, which established specific value ceilings to be achieved in 2020, covering issues of social inclusion and sustainable development. In November 2016, the European Commission outlined its strategic approach to implementing the 2030 Agenda for Sustainable Development, including the Sustainable Development Goals. Key actions to implement the 2030 Agenda for Sustainable Development [5]:

(1) Integrate the Sustainable Development Goals into a range of EU policies and initiatives, with sustainable development adopted as a guiding principle for all European Commission policies.

(2) Presenting regular reports on EU progress starting in 2017.

(3) To make progress in implementing the agenda in partnership with EU governments, the European Parliament, other European institutions, international organizations, civil society organizations, citizens and other stakeholders.

(4) Launch a high-level multi-stakeholder platform to promote the exchange of best practices in the cross-sectoral implementation of the Agenda at national and EU level.

(5) Announce a long-term vision for the period beyond 2020.

The adoption of sustainability principles for waste reduction should mean that in the future society must move to a situation where there is no waste, only waste transformation. This is because selected waste constitutes valuable raw materials, which after processing gain a "second life" (in the same or completely different form) or are used to generate energy (in the same or a completely different form) or used for energy production [33]. The European Union's interest in the waste problem dates back to the mid-1970s [34]. However, the perception of waste has changed since then-from treating it as a problem and something that needs to be disposed of, to now looking at waste as a potential source of benefit [35]. The basic legal act setting goals and targets for proper waste management in EU member states is Directive 2008/98/EC of the European Parliament and of the Council of 19 November 2008 on waste and repealing certain directives. The idea behind this legislation is to create legal measures to promote the concept of a society that seeks to eliminate waste generation and to use waste as a resource [36]. Similar solutions are being adopted by non-EU European countries. An example is Ukraine, which signed an association agreement with the European Union in 2014 and is in the process of economic reform. In Ukraine, waste policy is regulated by the Ukrainian Law "On Waste". However, the lack of infrastructure and insufficient activity at the local level significantly delays its implementation and expected effects [22]. The situation can be improved by the National Waste Management Plan to 2030 approved in 2019 by the Government of Ukraine, which is a kind of roadmap for the implementation of the National Waste Management Strategy (adopted in 2017) taking into account European waste management standards [37]. The main goals for improving waste management in Ukraine should include increasing waste sorting and recycling, and moving away from landfills [38]. 
Waste management plays a key role in a circular economy: it determines how the EU waste hierarchy is applied in practice. The waste hierarchy sets the order of priority from prevention, preparation for reuse, recycling and energy recovery to disposal such as landfill. This principle is intended to encourage options that provide the best overall environmental outcome. The Circular Economy Package includes concrete proposals to amend EU waste legislation to improve waste management practices, stimulate recycling and innovation in materials management, and reduce landfill [39].

The hierarchy of handling raw materials according to the ZW concept means avoiding the generation of waste and supporting the cyclical use of raw materials and creating incentives to stop waste. It is also the industrial design of products for reuse and return to circulation. Finally, it is the reuse, related to maintaining the function and value of products, and the recycling of residues in an environmentally safe way and close to the places of production [40]. In the context of municipal practice, the ZW rules communicate that the focus should be on optimizing existing waste management activities [25], which is reflected in urban waste policy-making. The ZW concept is, among other things, one of the areas of operation of the so-called eco-city, in which the well-being of residents is ensured and improved through integrated urban planning and management, with full use of green systems and renewable energy to zero emissions and avoid waste [41]. Many cities around the world are trying to achieve sustainable waste management goals and implement the principles of ZW [42]. However, this is not an easy task, especially in large urban areas [14].

More and more conscious consumers are concerned about environmental issues and the all too rapid depletion of natural resources [43]. They also see a connection between the state of the environment and their consumption choices [44]. In this context, $\mathrm{ZW}$ is a consumer response to the environmental damage caused by consumerist lifestyles and begins with purchasing and ends with proper treatment of the waste generated. $\mathrm{ZW}$ is a visionary lifestyle whereby people try to generate as little waste as possible, and thus not pollute the environment. ZW is both an ethical and economic goal that helps people emulate sustainable natural cycles in which all unnecessary materials are to become resources. ZW, among other things, also means making very responsible purchasing decisions. Conscious choices and putting fewer products in the shopping cart is the first step leading to reducing the amount of polluting waste produced. The idea of non-waste also puts emphasis on using things as long as possible or as many times as possible. They can find new uses, be given to other people for free or be sold. This applies, for example, to unused clothes, furniture or household appliances [45]. This is evidenced by the numerous online services that are growing in popularity, providing local communities with an exchange of various types of items based on the changing demand for them, causing a waste-free lifestyle to develop in these communities [46]. Living according to ZW principles should boil down to five basic steps, i.e., refuse, reduce, reuse, repurpose and recycle [47].

Sustainable resource management requires three overarching goals: (1) producer responsibility at the root of the problem: design and industrial production, (2) consumer responsibility at the end of the cycle: consumption, waste management and disposal and (3) political responsibility, which is the glue between social and producer responsibility. $\mathrm{ZW}$ is a necessary prerequisite for the rest of the necessary actions to be taken in the areas of health, increasing social equity and achieving sustainable development. ZW can be linked to the sustainability of agriculture, construction, energy, industrial, economic and social sectors. Every resident produces waste and as such is part of a wasteful society. With good policies, everyone could be involved in making the transformation to a society that is more sustainable [48].

\section{Materials and Methods}

The research process of evaluating Zero Waste in the context of supporting environmental protection by consumers was carried out based on the following stages:

(1) Study preparation, i.e., establishing the purpose and method of the study, determining the statistical community and the characteristics to be included in the research. 
(2) Collecting statistical material (survey implementation-primary source).

(3) Development and presentation of statistical material, involving grouping and counting and appropriate presentation of statistical data in the form of statistical series, tables, charts, graphs, etc.

(4) Description or statistical inference.

The research was carried out using the CAWI method (Computer-Assisted Web Interview). The research tool was a structured questionnaire. The questionnaire was prepared by authors of the presented article, who have experience in the implementation of quantitative research and the construction of research tools, in particular the questionnaire. The questionnaire was consulted with sociologists at the universities affiliated by authors. The self-administered survey questionnaire consisted of an introduction to the survey (indicating the essence of the study), 5 questions on the so-called metric (age, gender, place of residence and education) and 24 questions covering the problem of knowledge about ZW. It was prepared in google forms [49]. The link to the survey was made available through a variety of communication platforms (which was important to the authors in view of the Covid-19 epidemic). The survey allowed a large group of respondents to be reached. Before the research, a pilot study was carried out (its participants were people with different demographic characteristics from the countries covered by the study). Due to the fact that the study was conducted during the Covid-19 pandemic, the authors, choosing the CAWI method, decided to select a non-random sample for the study.

The survey was conducted between January and June 2021 on a group of residents of Poland, the Czech Republic, Slovakia and Ukraine. The authors of the study intentionally selected countries due to their location in Central and Eastern Europe. These are neighboring countries belonging to the EU (Poland, Slovakia and the Czech Republic) and those outside its structures (a country aspiring to the EU-Ukraine and benefiting from experiences from other countries). The selected countries, despite the same legal regulations at the EU level, differ significantly in the area of waste management [50]. In the case of Czech Republic only a few filled in questionnaires were received, therefore in the section about research results, the country is not included.

Simple statistical methods were used to analyze data collected from surveys. In the analysis of survey data we deal with the analysis of summaries, analysis of individual data (single questions) and analysis of aggregate data sets. Most of the questions include quantitative data, some questions also include qualitative data. Survey analysis requires the collation of data in various combinations. Survey data analysis focuses on analytical summaries for each question separately. When talking about relationships (interdependencies) between variables, correlations between them are indicated. To investigate empirical distributions one can use description of data collected in survey questionnaire, tables of numbers or their graphical presentation in form of charts (pie-charts, histogram and box-and-whisker). Their discussion ends with conclusions. Conclusions from the research are cognitive (research results contain information about the analyzed problem) as well as applied. Application conclusions are postulates (recommendations) formulated by the authors on the basis of the obtained results.

The vast majority of survey data are counts (referring to individual (disjoint), or multicriteria selection - where the sum of responses does not add up to the sum of surveys). The reference basis of the analysis is the list of surveys ( $\mathrm{N}$ number of surveys) containing answers to a given question. Respondents did not always answer all the questions contained in the survey questionnaire, so the $\mathrm{N}$ number (referring to the country) in individual questions may differ.

To examine the relationship between two variables measured on a nominal scale, the $\chi^{2}$ test of independent groups was used. It tests the hypothesis $\mathrm{H}_{0}$ assuming that the variables under study are independent against the alternative hypothesis $\mathrm{H}_{1}$ stating that they are dependent. The $\chi^{2}$ test is based on the comparison of observed values (obtained 
in the study) and theoretical values (calculated under the assumption that there is no relationship between the variables) according to the formula:

$$
\chi^{2}=\sum_{\mathrm{i}=1}^{\mathrm{k}} \sum_{\mathrm{j}=1}^{\mathrm{k}} \frac{\left(\mathrm{n}_{\mathrm{ij}}-\hat{\mathrm{n}}_{\mathrm{ij}}\right)^{2}}{\hat{\mathrm{n}}_{\mathrm{ij}}}
$$

where:

$\mathrm{n}_{\mathrm{ij}}$-observed counts.

$\hat{\mathrm{n}}_{\mathrm{ij}}$-theoretical counts.

The test statistic assuming $\mathrm{H}_{0}$ is true has a $\chi^{2}$ distribution with $(\mathrm{k}-1) \cdot(\mathrm{n}-1)$ degrees of freedom (df). The assumed significance level (p) for the analyses was 0.05 [51].

Student's $t$-test for independent groups is used to verify hypothesis about equality of means of tested variable in two populations. Basic conditions of use: measurement on an interval scale, normality of the distribution of the tested variable in both populations, independent model, equality of variance of the tested variable of both populations. The test statistics are of the form:

$$
\mathrm{t}=\frac{\overline{\mathrm{x}}_{1}-\overline{\mathrm{x}}_{2}}{\sqrt{\frac{\left(\mathrm{n}_{1}-1\right) s d_{1}^{2}+\left(\mathrm{n}_{2}-1\right) s d_{2}^{2}}{\mathrm{n}_{1}+\mathrm{n}_{2}-2}}\left(\frac{1}{\mathrm{n}_{1}}+\frac{1}{\mathrm{n}_{1}}\right)}
$$

where:

$\overline{\mathrm{x}}_{1}, \overline{\mathrm{x}}_{2}$ averages in the first and second sample.

$\mathrm{n}_{1}, \mathrm{n}_{2}$ counts in the first and second sample.

$s d_{1}^{2}, s d_{21}^{2}$ variances in the first and second sample.

The test statistic has a Student's $t$ distribution with $\mathrm{df}=\mathrm{n}_{1}+\mathrm{n}_{2}-2$ degrees of freedom. The $p$-value determined by the test statistic is compared with the significance level $(\alpha=0.05)$. If $p \leq \alpha$, we reject hypothesis $\mathrm{H}_{0}$ by accepting $\mathrm{H}_{1}$, and $p>\alpha$ there is no reason to reject hypothesis $\mathrm{H}_{0}$ [51].

The calculations of the indicated tests within the article were performed for $\chi^{2}$ (chisquare test for large tables) in the program PQStat, for student's $t$ (for independent samples with respect to the variable) in Statistica software.

\section{Results and Discussion}

Global pollution and degradation of the natural environment, as well as the lack of prospects for rapid self-purification, force society to undertake actions aimed at sustainable development. One of the elements of such a policy is the creation and enforcement of regulations in environmental protection, especially in terms of organizing waste management [52-54]. Problems of excessive amount of waste are an important issue referring to the quality of human life and existence. Increasing financial means for environmental protection is as important as shaping ecological awareness which may allow for the sense of order and safety in the future and consistent action of economic entities within the idea of sustainable development to be created $[55,56]$.

The sustainability of the environment is linked not only to environmental protection, but also to the exploitation of natural resources, primarily fossil fuels, with particular reference to the open-cast method. On top of that, there are deforestation, fishing, farming and cultivation and animal hunting. It can be said that every part of the environment is under threat: land, air and water. Elimination of these threats on the scale of a single country cannot be effective, because most threats have a supra-regional character, spreading far beyond the place where they occur [57].

In all, 821 respondents from three countries took part in the quantitative study, of which 503 were from Poland, 180 were from Slovakia and 138 were from Ukraine (Table 1). 
Table 1. Characteristics of respondents.

\begin{tabular}{|c|c|c|c|c|c|c|c|}
\hline & & Poland & Ukraine & Slovakia & Poland & Ukraine & Slovakia \\
\hline & & $N=503$ & $\mathbf{N}=138$ & $\mathrm{~N}=180$ & $\%$ & $\%$ & $\%$ \\
\hline \multirow{2}{*}{ Gender } & female & 357 & 80 & 130 & 70.97 & 57.97 & 72.22 \\
\hline & male & 146 & 58 & 50 & 29.03 & 42.03 & 27.78 \\
\hline \multirow{7}{*}{ Age } & below 18 & 2 & 12 & 0 & 0.40 & 8.70 & 0.00 \\
\hline & 18-24 & 344 & 84 & 42 & 68.39 & 60.87 & 23.33 \\
\hline & $25-34$ & 63 & 16 & 34 & 12.52 & 11.59 & 18.89 \\
\hline & $35-44$ & 33 & 16 & 40 & 6.56 & 11.59 & 22.22 \\
\hline & $45-54$ & 35 & 6 & 30 & 6.96 & 4.35 & 16.67 \\
\hline & 55-64 & 18 & 4 & 16 & 3.58 & 2.90 & 8.89 \\
\hline & above 64 & 8 & 0 & 18 & 1.59 & 0.00 & 10.00 \\
\hline \multirow{4}{*}{ Education } & basic & 5 & 8 & 2 & 0.99 & 5.80 & 1.11 \\
\hline & professional & 6 & 8 & 2 & 1.19 & 5.80 & 1.11 \\
\hline & secondary & 308 & 30 & 18 & 61.23 & 21.74 & 10.00 \\
\hline & higher & 184 & 92 & 158 & 36.58 & 66.67 & 87.78 \\
\hline \multirow{5}{*}{ Place of residence } & village & 241 & 18 & 56 & 47.91 & 13.04 & 31.11 \\
\hline & city below 10 thous. residents & 33 & 34 & 10 & 6.56 & 24.64 & 5.56 \\
\hline & city $10,1-50$ thous. residents & 83 & 24 & 10 & 16.50 & 17.39 & 5.56 \\
\hline & city $50,1-100$ thous. residents & 27 & 22 & 82 & 5.37 & 15.94 & 45.56 \\
\hline & city above 100 thous. residents & 119 & 40 & 22 & 23.66 & 28.99 & 12.22 \\
\hline
\end{tabular}

Source: own research.

The vast majority of respondents in the surveyed countries (90\% in Poland, $94 \%$ in Ukraine and $80 \%$ in Slovakia), recognize the problem of environmental degradation. Economic development, mass production and consumption, population growth have led and continue to lead to increasing adverse human impact on the environment. Research results published in the Special Eurobarometer Report concerning the attitudes of European citizens toward environment [58] show that 53\% of citizens in all EU Member States reckon that protecting the environment is personally very significant to them, while $43 \%$ of Europeans consider it as quite important (in Poland, respectively, $42 \%$ and $46 \%$, in Slovakia $47 \%$ for each). In turn, more than three-quarters of respondents agree that environmental issues have a direct impact on their daily life and health. However, the mere awareness of this influence does not guarantee the right attitudes of society. Behavioral changes in this area are long-term and do not occur at once [59].

In order to check whether there is a relationship (dependence) between the answers of the respondents on the problems of environmental degradation in Poland, Ukraine and Slovakia, a $\chi^{2}$ (Pearson) test was conducted. The results obtained at $p=0.05$ indicate that there is no statistically significant relationship between the answers of the respondents from Poland and Ukraine in relation to the country. In the other cases of Poland-Slovakia, Ukraine-Slovakia relationship, the data indicate a significant relationship in the responses on environmental degradation (Table 2).

Currently the most important threats to the environment are considered to be: the greenhouse effect, destruction of the ozone layer, threat to biodiversity, acid rain, drinking water deficit and the amount of waste produced. The biggest problem related to globalization that respondents indicate is production of too much waste $(38.42 \%$ Poland, $32.35 \%$ Ukraine and 33.77\% Slovakia), excessive consumption (25.15\% Poland, 32.35\% Ukraine and $40.35 \%$ Slovakia) and lack of people's awareness about environmental pollution ( $34.93 \%$ Poland, $34.71 \%$ Ukraine and $25.44 \%$ Slovakia). Respondents at maximum $1 \%$ level indicate that they do not see any problems and that they are not interested in that.

Consumers' decisions should be made taking into account the aspects of social responsibility (for the environment), although the basic determinants of choice, which mainly include needs, preferences and possibilities of their implementation, cannot be ignored [60]. The consumption model of a household depends on the life cycle of the household, the consumption pattern of the household members, and the amount of income [61]. The problem of producing too much waste in households, results, among other things, from the fact that consumers buy goods that turn into waste very quickly. Currently, many 
goods on the market are perishable and quickly damaged. This happens, inter alia, due to the strategies of producers who supply the market with items with a short useful life, perishable, intended to be replaced quickly [62]. Additionally, the more and more sophisticated forms of new packaging used by producers generate problems of excessive mass of undeveloped waste. An important role in their recycling should be played by the pro-ecological awareness of consumers (including in the aspect of Zero Waste) [63].

Table 2. Results of the $\chi^{2}$ test for the relationship between the studied countries in the area of the problem of environmental degradation under globalization.

\begin{tabular}{cc}
\hline Country-Country Relationship & $\chi^{2}$ (Pearson) \\
\hline Poland vs. Ukraine & $\chi^{2}$ (Pearson) $=3.079163$ \\
$\mathrm{df}=2$ \\
$p=0.214471$ \\
\hline Poland vs. Slovakia & $\chi^{2}($ Pearson $)=28.710732$ \\
& $\mathrm{df}=2$ \\
& $p=0.000001$ \\
\hline Ukraine vs. Slovakia & $\chi^{2}$ (Pearson $)=13.401941$ \\
$\mathrm{df}=2$ \\
\end{tabular}

The $\chi^{2}$ test for large tables. Source: own research.

The results of the report of the Ministry of the Environment of the Republic of Poland on waste management [64] show that people with the highest incomes more often take measures to reduce the amount of waste they generate at home $(64.8 \%)$ than people with the lowest incomes (54.5\%). However, more interesting than the practice itself are the reasons for the lack of this type of action. For the lowest earners, the most frequently indicated reason is the lack of knowledge on how to reduce the amount of waste $(41.6 \%$ of responses, while in the group of the highest earners this answer was indicated by $27.3 \%$ of respondents). However, for the highest earners, the main reason for not taking action to reduce the amount of generated waste is the fact that it is not important to them (29.5\% of respondents with the highest income indicated this answer, while among the lowest earners-only 10.4\%) [65].

The results of the $\chi^{2}$ (Pearson) test indicate statistically significant relationships between the responses of respondents from the studied countries in terms of global problems related to environmental degradation (at $p=0.05$ ). Thus, the problem of environmental degradation is recognized, which can be indicated by the analysis of the relationship between excessive consumption and the production of too much waste $(p=0.000019)$, or the lack of awareness of people about environmental pollution, and the consequences associated with it ( $p=0.000001)$. To eliminate threats to the environment, it is necessary to increase environmental awareness of the entire international community. It is also extremely important to mobilize resources and use them effectively and in a planned manner to prevent further environmental degradation. In the case of the $\chi^{2}$ test, the relations between the studied countries in the area of global problems related to environmental degradation are presented in Table 3.

The results indicate that most of them know the concept $(69.38 \%$ Poland, $71.01 \%$ Ukraine and $86.67 \%$ Slovakia). As a result of the $\chi^{2}$ (Pearson) test analysis, a statistically significant relationship was observed between the countries in the response about the knowledge of the ZW concept (Table 4 ). The $\chi^{2}$ (Pearson) test analysis between countries shows that there is no relationship between the answers of respondents between Poland and Ukraine $(p=0.711829)$. In the case of Poland-Slovakia $(p=0.000006)$, Ukraine-Slovakia $(p=0.00056)$, statistically significant relationships in the study area were indicated. 
Table 3. Results of $\chi^{2}$ test for the relationship between the studied countries in the area of global problems related to environmental degradation.

\begin{tabular}{cc}
\hline Country-Country Relationship & $\chi^{2}$ (Pearson) \\
\hline Poland vs. Ukraine & $\chi^{2}$ (Pearson) $=9.948471$ \\
& $\mathrm{df}=4$ \\
& $p=0.041305$ \\
\hline Poland vs. Slovakia & $\chi^{2}$ (Pearson) $=38.866976$ \\
& $\mathrm{df}=4$ \\
& $p=0.000001$ \\
\hline Ukraine vs. Slovakia & $\chi^{2}$ (Pearson $)=13.355381$ \\
& $\mathrm{df}=4$ \\
& $p=0.009664$ \\
\hline
\end{tabular}

The $\chi^{2}$ test for large tables. Source: own research.

Table 4. Knowledge of the ZW concept among respondents from Poland, Ukraine and Slovakia.

\begin{tabular}{|c|c|c|c|c|}
\hline \multirow{2}{*}{$\begin{array}{l}\text { Knowledge of the } \\
\text { ZW Concept }\end{array}$} & & Poland & Ukraine & Slovakia \\
\hline & $\mathbf{N}$ & 503 & 138 & 180 \\
\hline Yes & \multirow{2}{*}{$\%$} & 69.38 & 71.01 & 86.67 \\
\hline No & & 30.62 & 28.99 & 13.33 \\
\hline \multicolumn{2}{|c|}{$\chi^{2}$ (Pearson)* } & \multicolumn{3}{|c|}{$\begin{array}{c}\chi^{2} \text { (Pearson) }=20.806711 \\
\mathrm{df}=2 \\
p=0.00003\end{array}$} \\
\hline
\end{tabular}

* Chi-square test for large tables. Source: own research.

$\mathrm{ZW}$ is a lifestyle that involves reducing waste production. It involves reducing waste from shopping, through use (i.e., proper storage of food, care of clothes and maintenance of equipment) to disposal (i.e., composting of kitchen waste). The most important principles of ZW can be summarized as refuse (refuse, do not buy unnecessary things), reduce (reduce the number of things you buy), reuse (avoid single-use solutions), recycle (separate and recycle raw materials, segregate waste), rot (compost organic waste) or repair (repair, do not throw away right away) [66]. Among the surveyed respondents $52.49 \%$ in Poland, $53.62 \%$ in Ukraine and $68.89 \%$ in Slovakia declare knowledge of the principles of the ZW concept, the rest indicate their ignorance (Table 5).

Table 5. Knowledge of the ZW principles among respondents from Poland, Ukraine and Slovakia.

\begin{tabular}{|c|c|c|c|c|}
\hline \multirow{2}{*}{$\begin{array}{c}\text { Knowledge of the ZW } \\
\text { Principles }\end{array}$} & \multicolumn{2}{|r|}{ Poland } & Ukraine & Slovakia \\
\hline & $\mathbf{N}$ & 503 & 138 & 180 \\
\hline Yes & \multirow{2}{*}{$\%$} & 52.49 & 53.62 & 68.89 \\
\hline No & & 47.51 & 46.38 & 31.11 \\
\hline$\chi^{2}$ (Pearson) * & & & $\begin{array}{c}\text { rson) }=14 \\
d f=2 \\
=0.000562\end{array}$ & \\
\hline
\end{tabular}

* Chi-square test for large tables. Source: own research.

The concept of ZW follows the trend of sustainable development and is based on the idea of a circular economy where everything can be reused to avoid dumping waste in landfills [67]. Research by Watson and Smith [68] shows that respondents agree with ZW core principles such as waste avoidance, reuse, recycling and reducing waste, but often lack knowledge on how to effectively implement these principles. The research of Saplacan and Marton [69] shows that people who follow the rules of ZW are individualists living according to their own rules. They also usually have a positive attitude towards other users who live in accordance with ZW. At the same time, universal adoption of the 
lifestyle according to ZW is limited by conformism of the generally accepted lifestyle. This barrier is likely to disappear when the number of people in the society who adhere to the ZW principles reaches a critical mass. According to Zaman [70], the basic issue related to the implementation of ZW principles in everyday life is education. ZW needs a new generation of people who understand the problem of waste and distinguish what is waste and what is not.

In order to check if there is a statistically significant relationship between the answers of respondents concerning knowledge of the ZW principles in Poland, Ukraine and Slovakia, $\chi^{2}$ (Pearson) test was performed. The results obtained at $p=0.05$ indicate that there is no such relationship in the case of Poland-Ukraine $(p=0.812485)$. In the case of Poland-Slovakia, Ukraine-Slovakia the results indicate a significant relationship in the responses about the knowledge of the principles of ZW concept (at $p=0.05$ ) (Table 6).

Table 6. Results of $\chi^{2}$ test for the relationship between the studied countries in the area of knowledge of ZW concept.

\begin{tabular}{cc}
\hline Country-Country Relationship & $\chi^{2}$ (Pearson) \\
\hline Poland vs. Ukraine & $\chi^{2}$ (Pearson) $=0.056274$ \\
$\mathrm{df}=1$ \\
$p=0.812485$ \\
\hline Poland vs. Slovakia & $\chi^{2}($ Pearson $)=14.537722$ \\
& $\mathrm{df}=1$ \\
& $p=0.000137$ \\
\hline Ukraine vs. Slovakia & $\chi^{2}$ (Pearson) $=7.747574$ \\
& $\mathrm{df}=1$ \\
& $p=0.005378$ \\
\hline
\end{tabular}

The $\chi^{2}$ test for large tables, performed in PQStat software. Source: own research.

$\mathrm{ZW}$ is an environmental trend that is gaining more and more interest among the societies of the studied countries. The ZW concept includes waste reduction, recycling and savings due to lower consumption of electricity and water. The idea of ZW fits perfectly into the trend, which involves the transformation of natural raw materials to produce new materials. This allows us to take more responsibility for the environment around us [71].

According to respondents in the surveyed countries, the ZW concept is mainly associated with segregation of waste (12.98\% Poland, 17.88\% Ukraine and $16.61 \%$ Slovakia), reducing plastic consumption (respectively, 19. 35\%, 18.25\% and 22.04\%), not throwing away clothes (giving them to others, exchanging clothes $(17.13 \%, 16.42 \%$ and $13.42 \%$ ), not throwing away food $(14.78 \%, 11.68 \%$ and $15.02 \%)$ or thoughtful shopping $(17.07 \%, 12.41 \%$ and $15.65 \%$, Table 7 ). The results of the $\chi^{2}$ (Pearson's) test indicate a significant relationship within the indicated associations of the ZW concept on a country to country basis (Poland vs. Ukraine $\chi^{2}=13.922065, \mathrm{df}=6 p=0.03051$; Poland vs. Slovakia $\chi^{2}=43.133206 ; \mathrm{df}=6$ $p=0.000001 ;$ Ukraine vs. Slovakia $\chi^{2}=29.300517 ; \mathrm{df}=6 p=0.000053$; at $\left.p=0.05\right)$. Analysis of the results of the $\chi^{2}$ test between the elements associated by respondents with the ZW concept indicates a statistically significant relationship between waste segregation and thoughtful shopping $\left(\chi^{2}\right.$ (Pearson) $=8.438071$, $\left.\mathrm{df}=2, p=0.014713\right)$, as well as between waste segregation and saving utilities in households (electricity-turning off unnecessarily lit lights, water conservation; $\chi^{2}$ (Pearson) $=30.195461$, $\mathrm{df}=2, p=0.000001$ ), or between thoughtful shopping and paper consumption, e.g., online billing ( $\chi^{2}$ (Pearson) $=13.585946$, $\mathrm{df}=2, p=0.001122$ ). 
Table 7. Elements identified with the ZW concept by respondents from Poland, Ukraine and Slovakia.

\begin{tabular}{|c|c|c|c|c|}
\hline Elements of the ZW Concept & & Poland & Ukraine & Slovakia \\
\hline & $\mathrm{N}$ & 1664 & 274 & 313 \\
\hline Waste segregation & & 12.98 & 17.88 & 16.61 \\
\hline Reducing the use of plastics & & 19.35 & 18.25 & 22.04 \\
\hline $\begin{array}{l}\text { Reducing paper consumption } \\
\text { (e.g., online bills) }\end{array}$ & & 9.92 & 14.6 & 16.93 \\
\hline $\begin{array}{l}\text { Not throwing clothes away } \\
\text { (giving them to others, exchanging clothes) }\end{array}$ & $\%$ & 17.13 & 16.42 & 13.42 \\
\hline Not throwing food away & & 14.78 & 11.68 & 15.02 \\
\hline Thoughtful shopping & & 17.07 & 12.41 & 15.65 \\
\hline $\begin{array}{l}\text { Saving utilities in households } \\
\text { (electricity-turning off unnecessarily lit } \\
\text { lights, saving water) }\end{array}$ & & 8.77 & 8.76 & 0.32 \\
\hline$\chi^{2}$ (Pearson) * & & \multicolumn{3}{|c|}{$\begin{array}{c}\left.\chi^{2} \text { (Pearson }\right)=53.346417 \\
\mathrm{df}=12 \\
p=0.000001\end{array}$} \\
\hline
\end{tabular}

The results of the Global Consumer Insights Survey 2020 [72] by PricewaterhouseCoopers among consumers from 27 countries or territories and 74 cities in 2019 show clear support for sustainable development and a sense of civic duty. The survey found that $45 \%$ of respondents said they avoid plastic as much as possible, $43 \%$ expected companies to be responsible for their environmental impact and $41 \%$ expect that retailers will eliminate plastic bags and perishable packaging. Moreover, when asked who is most responsible for promoting sustainable behavior in their city, $20 \%$ of consumers chose the answer "I the consumer", and 15\% chose "producers". Therefore, a good direction in the field of environmental protection and support for the ZW principle is, for example, the development of stores offering products without packaging. Publication entitled "Packaging free shops in Europe an initial report" [73], shows the results of the survey conducted in 10 countries (Austria, Belgium, Bulgaria, Czech Republic, France, Germany, Latvia, Slovenia, Spain and Ukraine) in packaging free 268 shops, which indicate that:

(1) There is a strong increase in job growth within the sector, with modelling presenting a mean estimate of 10,000 jobs in packaging free shops across Europe in 2023.

(2) Estimated EU wide avoided packaging in 2023 as a result of packaging free shops is approximately 5500 tonnes.

(3) Packaging free shops estimate to have avoided, on average, 1 tonne of packaging per year per shop.

(4) Approximately $70 \%$ of products within the shops sampled are packaging free.

(5) Food and drink products are the most sold, followed by cosmetic products, cleaning products and ZW accessories.

Socio-economic development, regardless of the rate at which it is taking place, is inextricably linked with the generation of waste. The increase in single-use packaging and its material diversity have given rise to very serious problems resulting from the need to manage the increasing mass of waste. It is necessary to analyze the assessment of the fulfilment of economic, social, ecological or ethical goals within the ZW concept.

Waste is also generated from food wastage, so it is important to strive for the sustainability of food systems. The food system must incorporate changes in management and behavior to assess quality, food waste and production. Practical solutions must focus on increasing environmental friendliness, labeling products to prove authenticity and reusing and recycling products [74]. This also is connecting with sustainable industry [75]. 
The analysis of the $\chi^{2}$ test (Pearson) indicates a significant relationship between the goals (economic, social, environmental and ethical) of the ZW concept. Respondents in Poland in terms of fulfilling the goals by ZW concept indicated above all the ecological (58.66\% - very well fulfils this goal), social $(33.06 \%-3 ; 31.84 \%-4)$, economic $(28.66 \%-3$; $29.88 \%-4)$ and ethical $(29.86 \%-5)$ goals. In case of respondents from Ukraine, they also indicated ecological $(55.22 \%-5)$, ethical $(46.27 \%-5)$, social $(36.76 \%-4)$ and economic $(33.82 \%-4)$ purpose. Slovak respondents' ratings were similarly distributed (ecological $66.67 \%$-5; social $35.23 \%$-4; ethical $29.55 \%$-5; economic $26.67 \%$-4 Table 8 ).

Table 8. Assessment of the fulfilment of economic, social, ecological and ethical goals by ZW concept in the opinion of respondents from Poland, Ukraine and Slovakia (scale of 1-5, where 1-does not meet this goal in general and 5-meets this goal very well).

\begin{tabular}{|c|c|c|c|c|c|c|c|}
\hline \multirow{2}{*}{ Goals } & & \multicolumn{5}{|c|}{ Scale } & \multirow[b]{2}{*}{$\chi^{2}$ (Pearson) * } \\
\hline & & 1 & 2 & 3 & 4 & 5 & \\
\hline & $\mathrm{N}$ & \multicolumn{5}{|c|}{ Poland (\%) } & \\
\hline economic & 492 & 3.66 & 9.96 & 28.66 & 29.88 & 27.85 & \multirow{4}{*}{$\begin{array}{c}\chi^{2} \text { (Pearson) }=188.914285 \\
\mathrm{df}=12 \\
p=0.000001\end{array}$} \\
\hline social & 490 & 3.47 & 10.20 & 33.06 & 31.84 & 21.43 & \\
\hline ecological & 491 & 1.63 & 3.87 & 14.05 & 21.79 & 58.66 & \\
\hline \multirow[t]{2}{*}{ ethical } & 489 & 4.50 & 10.43 & 27.61 & 27.61 & 29.86 & \\
\hline & $\mathrm{N}$ & & & raine & & & \\
\hline economic & 136 & 7.35 & 5.88 & 22.06 & 33.82 & 30.88 & \multirow{4}{*}{$\begin{array}{c}\left.\chi^{2} \text { (Pearson }\right)=61.656268 \\
\mathrm{df}=12 \\
p=0.000001\end{array}$} \\
\hline social & 136 & 0.00 & 10.29 & 22.06 & 36.76 & 30.88 & \\
\hline ecological & 134 & 0.00 & 4.48 & 14.93 & 25.37 & 55.22 & \\
\hline \multirow[t]{2}{*}{ ethical } & 134 & 0.00 & 5.97 & 8.96 & 38.81 & 46.27 & \\
\hline & $\mathrm{N}$ & & & vakia & & & \\
\hline economic & 180 & 5.56 & 10.00 & 33.33 & 26.67 & 24.44 & \multirow{4}{*}{$\begin{array}{c}\chi^{2} \text { (Pearson) }=127.121349 \\
\mathrm{df}=12 \\
p=0.000001\end{array}$} \\
\hline social & 176 & 1.14 & 9.09 & 34.09 & 35.23 & 20.45 & \\
\hline ecological & 180 & 5.56 & 1.11 & 15.56 & 11.11 & 66.67 & \\
\hline ethical & 176 & 4.55 & 12.50 & 25.00 & 28.41 & 29.55 & \\
\hline
\end{tabular}

* Chi-square test for large tables. Source: own research.

Sustainable development is not a uniform and unambiguously defined category. It is an undefined concept, changing in time and space. Understanding the economic, social, ecological and ethical goals of ZW concept and their interrelations may contribute to the improvement of current waste management systems, implementation of good practices in this area [76], as well as use of natural resources. Modern and future socio-economic development should be realized taking into account more efficient use of natural resources. In the environmental aspect, this requires not only limiting the consumption of natural resources, but above all, shifting the focus from the intensive use of non-renewable raw materials to the use of renewable raw materials.

In order to check whether the answers concerning the goals (economic, social, ecological and ethical) met by the ZW concept differ significantly between the respondents from Poland, Ukraine and Slovakia, Student's $t$-test for independent samples was performed. Its results indicate statistically significant differences in the aspect of economic goal between Poland and Ukraine $(t=2.53190067, \mathrm{df}=8, p=0.0351512515)$, social goal between Poland and Ukraine ( $t=2.35772197, \mathrm{df}=8, p=0.0461219388)$, ethical between Poland and Ukraine $(t=2.49533273, \mathrm{df}=8, p=0.0372116905)$ and Poland and Slovakia $(t=2.32333591, \mathrm{df}=8$, mboxemphp $=0.0486653377$-Table 9). 
Table 9. Student's t-scores for independent samples for relationships between economic, social, environmental and ethical goals indicated by respondents from Poland, Ukraine and Slovakia.

\begin{tabular}{cccc}
\hline Goals & Poland vs. Ukraine & Poland vs. Slovakia & Ukraine vs. Slovakia \\
\hline \multirow{2}{*}{ economic } & $\mathrm{t}=2.53190067$ & $\mathrm{t}=2.18208497$ & $\mathrm{t}=-0.715092745$ \\
& $\mathrm{df}=8$ & $\mathrm{df}=8$ & $\mathrm{df}=8$ \\
& $p=0.0351512515$ & $p=0.0606649658$ & $p=0.49488832$ \\
\hline \multirow{2}{*}{ social } & $\mathrm{t}=2.35772197$ & $\mathrm{t}=2.02798121$ & $\mathrm{t}=0.535383$ \\
& $\mathrm{df}=8$ & $\mathrm{df}=8$ & $\mathrm{df}=8$ \\
& $p=0.0461219388$ & $p=0.0770983105$ & $p=0.606942645$ \\
\hline \multirow{2}{*}{ ecological } & $\mathrm{t}=1.36353431$ & $\mathrm{t}=1.13024795$ & $\mathrm{t}=-0.365309539$ \\
& $\mathrm{df}=8$ & $\mathrm{df}=8$ & $\mathrm{df}=8$ \\
& $p=0.209844705$ & $p=0.291116862$ & $p=0.724350118$ \\
\hline \multirow{2}{*}{ ethical } & $\mathrm{t}=2.49533273$ & $\mathrm{t}=2.32333591$ & $\mathrm{t}=-0.55044406$ \\
& $\mathrm{df}=8$ & $\mathrm{df}=8$ & $\mathrm{df}=8$ \\
& $\mathrm{t}=0.0372116905$ & $p=0.0486653377$ & $p=0.597045111$
\end{tabular}

Source: own research.

In the economics of sustainable development, special importance is attached to natural resources. They are the input for production, are the basis for the existence of humans and other living beings. Ecological economics (in sustainability economics) seeks to create a sustainable social system with a high quality of life for all inhabitants within natural limits. In this insight, therefore, attention is drawn to an interdisciplinary approach that goes beyond a purely economic approach and seeks to analyze economic processes in an economic-social-ecological context [1].

Balancing the role of economic, ecological and social aspects of waste management has led to the formation of changes in the indicated aspect. These are successively the following: prevention of generation, preparation for reuse, recycling, other recovery processes and disposal. Waste management is one of the specific fields of widely understood activity of local authorities (municipalities), as well as it is shaped by households.

The survey conducted among respondents in Poland, Ukraine and Slovakia indicates that we most often segregate plastics (27.93\% Poland, 26.24\% Ukraine and $29.43 \%$ Slovakia), paper $(24.82 \%, 24.11 \%$ and $27.30 \%$, respectively) and glass $(27.11 \%, 19.86 \%$ and $24.11 \%)$. Still some respondents indicate that they do not segregate garbage at all (the highest number in Ukraine $14.18 \%$, Table 10). In the analyzed area, the results of $\chi^{2}$ (Pearson) test indicate a significant relationship in the analyzed area in relation Poland-Ukraine $\left(\chi^{2}\right.$ (Pearson) $\left.=190.10156, \mathrm{df}=4, p=0.000001\right)$ and Ukraine-Slovakia $\left(\chi^{2}\right.$ (Pearson $\left.)=76.413301, \mathrm{df}=4, p=0.000001\right)$, and a non-significant relationship was observed in relation Poland-Slovakia $\left(\chi^{2}\right.$ (Pearson) $=3.212262, \mathrm{df}=4, p=0.522953$ ).

The benefits of waste recovery are wide ranging. They include tangible material values, ecological, social and ethical effects. Waste management should consider recovery in its economic and ecological aspects [77]. In the European Union countries, in 2019, on average, $48 \%$ of municipal waste was recycled and composted, $28 \%$ was used for energy and the remaining $24 \%$ was landfilled (for $2 \%$ there is no data) [78]. In Poland in 2019, 34\% of municipal waste was recycled and composted. For Slovakia, this ratio was $38 \%$. The difference between Ukraine and other developed countries is that Ukraine produces a large amount of waste, with a simultaneous lack of infrastructure for its disposal. In 2019, the amount of solid waste generated in Ukraine amounted to over 11.5 million tonnes, which is about $280 \mathrm{~kg}$ per capita. The dominant method of disposing of household waste is its disposal and neutralization in landfills and dumping grounds [79]. In 2016 only $5.8 \%$ of the generated amount of municipal solid waste was recycled, of which $2.71 \%$ was incinerated, $3.09 \%$ was sent to other waste recycling complexes and about $0.003 \%$ was composted [80]. 
Table 10. Waste segregated at household level according to respondents from Poland, Ukraine and Slovakia.

\begin{tabular}{|c|c|c|c|c|}
\hline \multirow{2}{*}{ Waste Segregated in Household } & & Poland & Ukraine & Slovakia \\
\hline & $\mathbf{N}$ & 1704 & 282 & 564 \\
\hline Plastics & \multirow{5}{*}{$\%$} & 27.93 & 26.24 & 29.43 \\
\hline Paper & & 24.82 & 24.11 & 27.3 \\
\hline Glass & & 27.11 & 19.86 & 24.11 \\
\hline Biodegradable waste & & 19.6 & 15.6 & 18.79 \\
\hline I do not segregate waste & & 0.53 & 14.18 & 0.35 \\
\hline$\chi^{2}$ (Pearson) * & & & $\begin{array}{c}\text { rson) }=245 \\
\mathrm{df}=8 \\
b=0.00000\end{array}$ & \\
\hline
\end{tabular}

* Chi-square test for large tables. Source: own research.

Environmental protection is becoming a priority task for local communities. Production of consumer goods causes overexploitation of non-renewable natural resources of our planet. In order to prevent significant depletion of resources and to give a chance to the next generations, it is necessary to popularize the reuse of raw materials, to strengthen waste segregation aspect in the local economy. The biggest barriers connected with waste segregation were indicated by respondents as lack of knowledge on how to segregate waste $(9.89 \%$ Poland, $46.46 \%$ Ukraine and $19.19 \%$ Slovakia), lack of space at home for several waste baskets $(26.26 \%$, $37.37 \%$ and $29.29 \%$, respectively) and I do not see any barriers, because I segregate waste $(55.04 \%, 9.09 \%$ and $45.45 \%)$ (Table 11). The results of the $\chi 2$ (Pearson) test indicate a significant relationship between the respondents' answers in the aspect of barriers preventing waste segregation between Poland and Ukraine $(\chi 2$ (Pearson $)=178.627135, \mathrm{df}=4, p=0.000001)$, Poland vs. Slovakia $\left(\chi^{2}\right.$ (Pearson) $\left.=14.834929, \mathrm{df}=4, p=0.005056\right)$ and Slovakia vs. Ukraine $\left(\chi^{2}\right.$ (Pearson $\left.)=72.592385, \mathrm{df}=4, p=0.000001\right)$. The $\chi^{2}$ (Pearson) test for the relationship lack of space at home for several garbage cans vs. I think segregation is not needed indicates no significant relationship $\left(\chi^{2}\right.$ (Pearson) $\left.=0.78359, \mathrm{df}=2, p=0.675843\right)$.

$\mathrm{ZW}$ involves reducing littering at many stages-from shopping, through use (proper storage of food in order to meet consumption before it becomes rotten, caring for clothes and maintenance of the equipment so that they last as long as possible) to waste management (composting kitchen waste, remaking objects and giving them a second life). In Poland, $53.11 \%$ of respondents indicate that they apply and will continue to apply ZW principles, compared to in Ukraine $44.44 \%$ and in Slovakia 64.84\%. Respondents in Poland 1.75\%, Ukraine $2.78 \%$ and Slovakia $1.10 \%$ do not apply and have no intention to introduce them in their household (Table 12).

The ecological awareness of individuals depends on the views, beliefs and choices of a specific person, it is also an integral part of social awareness. The consequence of the increase in the level of environmental awareness among consumers is, inter alia, the interest in a healthy lifestyle and respect for natural resources. Responsible decisions related to the purchase of food directly translate into the state of the natural environment. Subsequently it brings economic, social, ethical and environmental benefits. Respondents in Poland, Ukraine and Slovakia indicate that applying ZW principles in daily life both brings (and does not bring) economic (35.38\% in Poland, 38.46\% in Ukraine and 32.94\% in Slovakia) and ecological (62.35\%, 56.92\%, 70.59), social (26\%, 54\%, 38.46\%, 35.71\%) and ethical $(36.88 \%, 41.54 \%, 42 \%$ and $35 \%$, Table 13$)$ benefits. Communities should strongly and actively participate in $\mathrm{ZW}$ activities (environmentally friendly activities). Activities that reduce the amount of garbage generated should be supported, with long-term benefits in improving air and water quality. 
Table 11. Barriers preventing waste segregation according to respondents from Poland, Ukraine and Slovakia.

\begin{tabular}{|c|c|c|c|c|}
\hline \multirow{2}{*}{ Waste Segregation Barriers } & & Poland & Ukraine & Slovakia \\
\hline & $\mathbf{N}$ & 556 & 198 & 198 \\
\hline $\begin{array}{l}\text { Lack of knowledge on the subject } \\
\text { (how to segregate) }\end{array}$ & \multirow{5}{*}{$\%$} & 9.89 & 46.46 & 19.19 \\
\hline $\begin{array}{l}\text { Lack of space in the house } \\
\text { for several waste bins }\end{array}$ & & 26.26 & 37.37 & 29.29 \\
\hline I believe that segregation is not necessary & & 2.34 & 2.02 & 2.02 \\
\hline I have not thought about it & & 6.47 & 5.05 & 4.04 \\
\hline I do not see barriers because I separate waste & & 55.04 & 9.09 & 45.45 \\
\hline$\chi^{2}$ (Pearson) * & & & $\begin{array}{c}\text { rson) }=179 \\
d f=8 \\
=0.00000\end{array}$ & 572 \\
\hline
\end{tabular}

* Chi-square test for large tables. Source: own research.

Table 12. Level of implementing ZW principles according to respondents from Poland, Ukraine and Slovakia.

\begin{tabular}{|c|c|c|c|c|}
\hline & & Poland & Ukraine & Slovak \\
\hline & $\mathbf{N}$ & 514 & 144 & 182 \\
\hline Yes, I do and I will continue & \multirow{5}{*}{$\%$} & 53.11 & 44.44 & 64.84 \\
\hline $\begin{array}{l}\text { I have used, but will not continue to use } \\
\text { because I see no tangible benefit }\end{array}$ & & 3.11 & 11.11 & 6.59 \\
\hline I do not use them, but I intend to & & 23.54 & 37.5 & 15.38 \\
\hline $\begin{array}{l}\text { I do not use and have no intention of } \\
\text { introducing them in my household }\end{array}$ & & 1.75 & 2.78 & 1.1 \\
\hline I have no opinion & & 18.48 & 4.17 & 12.09 \\
\hline$\chi^{2}$ (Pearson) * & & & $\begin{array}{c}\text { arson) }=55 \\
\quad \mathrm{df}=8 \\
p=0.00000\end{array}$ & \\
\hline
\end{tabular}

${ }^{*}$ Chi-square test for large tables. Source: own research.

Communities should decisively and actively participate in ZW activities (pro-ecological ones). Actions reducing the amount of waste generated should be supported, in order to bring long-term benefits in improving the quality of air and water. The choice of the above systems results from the assumptions of the concept of sustainable development indicating three groups of factors determining future development. These are economic, ecological and social factors. Student's $t$-test for independent samples is a comparison of two different groups of observations independent of each other. The results indicate significant differences between the responses of Polish and Ukrainian respondents in terms of the economic $(t=2.32256907, \mathrm{df}=8, p=0.0487236297)$ and social $(t=2.48733687, \mathrm{df}=8$, $p=0.0376782963$ ) benefits of the ZW activities (Table 14).

The presented research made it possible to fill in the information gaps in the aspect of $\mathrm{ZW}$ and its relation to the need for environmental protection by consumers. Moreover, significant awareness of the negative effects of overconsumption among respondents and the effect of too much rubbish contributing to environmental pollution was demonstrated. The research carried out in the countries of Central and Eastern Europe, divided into two countries belonging to the $\mathrm{EU}$, and one associated country with the $\mathrm{EU}$, are the basis for a broad scientific discussion and, consequently, for international cooperation of research centers. In addition, in the opinion of the authors, the results of the presented research constitute the basis for the continuation of empirical research in the field of waste 
management, and, consequently, for translating the conclusions into the area of legal regulations and educational programs, both at the EU and global level.

Table 13. ZW activities and its benefits for society according to respondents from Poland, Ukraine and Slovakia (scale of $1-5$, where 1 -does not meet this goal in general and 5-meets this goal very well).

\begin{tabular}{|c|c|c|c|c|c|c|c|}
\hline \multirow{2}{*}{ Goals } & & \multicolumn{5}{|c|}{ Scale } & \multirow[b]{2}{*}{$\chi^{2}$ (Pearson) $*$} \\
\hline & & 1 & 2 & 3 & 4 & 5 & \\
\hline & $\mathrm{N}$ & \multicolumn{5}{|c|}{ Poland (\%) } & \\
\hline economic & 424 & 5.66 & 8.49 & 24.76 & 25.71 & 35.38 & \multirow{4}{*}{$\begin{array}{c}\left.\chi^{2} \text { (Pearson }\right)=132.005414 \\
\mathrm{df}=12 \\
p=0.000001\end{array}$} \\
\hline social & 422 & 4.27 & 11.14 & 30.09 & 27.96 & 26.54 & \\
\hline ecological & 425 & 1.65 & 3.76 & 16.24 & 16.00 & 62.35 & \\
\hline \multirow[t]{2}{*}{ ethical } & 423 & 4.49 & 9.22 & 23.64 & 25.77 & 36.88 & \\
\hline & $\mathrm{N}$ & & & raine & & & \\
\hline economic & 130 & 9.23 & 1.54 & 21.54 & 29.23 & 38.46 & \multirow{4}{*}{$\begin{array}{c}\chi^{2}(\text { Pearson })=57.00179 \\
\mathrm{df}=12 \\
p=0.000001\end{array}$} \\
\hline social & 130 & 0.00 & 10.77 & 23.08 & 27.69 & 38.46 & \\
\hline ecological & 130 & 1.54 & 3.08 & 15.38 & 23.08 & 56.92 & \\
\hline \multirow[t]{2}{*}{ ethical } & 130 & 1.54 & 1.54 & 15.38 & 40.00 & 41.54 & \\
\hline & $\mathrm{N}$ & & & vakia & & & \\
\hline economic & 170 & 5.88 & 5.88 & 27.06 & 28.24 & 32.94 & \multirow{4}{*}{$\begin{array}{c}\chi^{2} \text { (Pearson) }=76.612516 \\
\mathrm{df}=12 \\
p=0.000001\end{array}$} \\
\hline social & 168 & 2.38 & 3.57 & 30.95 & 27.38 & 35.71 & \\
\hline ecological & 170 & 0.00 & 1.18 & 14.12 & 14.12 & 70.59 & \\
\hline ethical & 170 & 1.18 & 3.53 & 32.94 & 20.00 & 42.35 & \\
\hline
\end{tabular}

* Chi-square test for large tables. Source: own research.

Table 14. Student's $t$ test results for independent samples in terms of perceiving the benefits of zero waste for society (for relations between respondents from Poland, Ukraine and Slovakia).

\begin{tabular}{cccc}
\hline Goals & Poland vs. Ukraine & Poland vs. Slovakia & Ukraine vs. Slovakia \\
\hline \multirow{2}{*}{ economic } & $\mathrm{t}=2.32256907$ & $\mathrm{t}=1.97002838$ & $\mathrm{t}=-0.607176741$ \\
& $\mathrm{df}=8$ & $\mathrm{df}=8$ & $\mathrm{df}=8$ \\
& $p=0.0487236297$ & $p=0.0843399475$ & $p=0.560567535$ \\
\hline \multirow{2}{*}{ social } & $\mathrm{t}=2.48733687$ & $\mathrm{t}=2.04509785$ & $\mathrm{t}=-0.515969174$ \\
& $\mathrm{df}=8$ & $\mathrm{df}=8$ & $\mathrm{df}=8$ \\
& $p=0.0376782963$ & $p=0.0750773975$ & $p=0.619829791$ \\
\hline \multirow{2}{*}{ ecological } & $\mathrm{t}=1.21441859$ & $\mathrm{t}=0.98546355$ & $\mathrm{t}=-0.311493984$ \\
& $\mathrm{df}=8$ & $\mathrm{df}=8$ & $\mathrm{df}=8$ \\
& $p=0.259215767$ & $p=0.353258865$ & $p=0.763387888$ \\
\hline \multirow{2}{*}{ ethical } & $\mathrm{t}=2.14254227$ & $\mathrm{t}=1.78623593$ & $\mathrm{t}=-0.447773663$ \\
& $\mathrm{df}=8$ & $\mathrm{df}=8$ & $\mathrm{df}=8$ \\
& $p=0.0645204354$ & $p=0.111880652$ & $p=0.666193559$ \\
\hline
\end{tabular}

Source: own research.

Our study has some limitations. The category of household waste, namely drug/pharmaceutical waste, was not considered in the study. It is well known that this type of waste is not well managed by the population around the world (with few exceptions), which leads to water and soil contamination with various substances (chemicals) resulting from the degradation of medicinal products $[81,82]$. In the future, the research may be extended to include issues related to the management of pharmaceutical waste.

\section{Conclusions}

The natural environment is one of the basic factors influencing the quality of human life. It determines his well-being and affects his health. However, human interference led to its degradation, and the actions carried out for centuries have contributed to irreversible changes. Global pollution of the environment is mainly caused by over-industrialization, 
which is followed by over-consumption. To eliminate threats to the natural environment it is necessary to increase the environmental awareness of the entire international community. Effective legislation at a global level is extremely essential. One of the activities is the introduction, by means of individual legal regulations, rules regarding not only the broadly understood concept of sustainable development, but also introducing, at the level of individual countries, activities consistent with the principles of circular economy. All this is in line with the definition of $\mathrm{ZW}$, the principle of which is to operate within the natural cycles of renewal and processing of individual resources, and not their degradation.

Legislative activities, both at the national and community level, are in line with the postulates proposed by $\mathrm{ZW}$, which mean they consider it as the most important to take actions which match with the waste management hierarchy, starting from: (a) waste prevention, (b) preparation for re-use, (c) recycling, (d)other recovery operations and (e) disposal. Additionally, it should be noted that ZW, as a trend, relates to a greater extent to the everyday life of citizens as entities responsible for the production of municipal waste and encourages them to make more pro-environmental decisions related to everyday functioning, which may contribute to the improvement of the functioning of the entire municipal economic system.

The key issue was to determine the degree of awareness of the ZW problem among the respondents. The analysis of the collected research material from three countries of Poland, Slovakia and Ukraine allowed for the formulation of the following conclusions.

The results of the conducted research showed that the vast majority of respondents from the surveyed countries perceive the problem of environmental degradation. Moreover, importantly, a relationship was demonstrated in the respondents' responses in the relations between Poland and Slovakia as well as Ukraine and Slovakia. On the other hand, the results of the research showed that there was no statistically significant relationship between the responses of Polish and Ukrainian respondents. Data analysis pointed that environmental degradation is perceived as a significant problem, in particular, in terms of excessive consumption and the production of too much waste.

The analysis of data from the surveyed countries showed that the knowledge of the ZW concept was related to the elements of the daily functioning of households, such as waste segregation, reducing plastic consumption, donating clothes to others instead of throwing them away and not wasting food, which is related to with reasonable purchases. It should be emphasized that the respondents largely identify the above-mentioned activities with ZW theory. In addition, significant relationships between individual countries were demonstrated. It is essential and may constitute the basis for further activities, not only legislative but also educational, in the surveyed countries.

The conducted research showed a significant relationship between economic, social, ecological and ethical goals within the ZW concept. Importantly, the analysis of the research results showed that among the respondents of the surveyed countries the environmental goal is the most important, then the social and ethical one. It should be emphasized that the economic goal was usually indicated as the last one. The respondents do not connect activities that fit in the $\mathrm{ZW}$ with the economic aspect. As a part of educational activities, the economic aspect should be emphasized as the one that may be a priority in the activities of societies and will shape other elements related to $\mathrm{ZW}$, including social, ecological and ethical elements.

The authors, paying attention to the wide problem of environmental degradation, allow themselves to indicate, on the basis of the conducted research, recommendations in the field of the ZW concept, which is directly related to environmental protection.

Therefore, it would be advisable to strengthen the activities for the development of local environmental awareness and learning about the ZW concept through educational and information activities at the level of local authorities. These activities should be directed primarily to young learners, in line with the principle that young people should become promoters and advisors in the field of environmental protection. 
Moreover, it is vital to take pro-ecological actions not only by administrative units, but also by non-governmental organizations and local media.

It seems necessary to make an adjustment within the framework of the waste management policy of local authorities, which would allow for the natural implementation of the ZW principles into the life of households. This should let for a new look at the process of waste segregation and recycling itself, or the recycling of household appliances, clothes or other things. It will also be vital in operating local of the authorities to pay attention to the level of correlation between economic, ecological, social and ethical elements. Their effective activities in this area will require new co-financing programs, for example the replacement of coal stoves, photovoltaics, which should result in strengthening the environmental and economic goals in the ZW theory.

All these activities should lead to ZW becoming something natural in the functioning of households, pointing, in particular, to such activities as thoughtful choices, cessation from mindless consumerism, care for the environment, a healthier life and the future of our planet.

Author Contributions: Conceptualization, M.B., R.M.-P., A.K., P.D.; methodology, M.B., R.M.-P., A.K., P.D.; software, M.B., R.M.-P., A.K., P.D.; validation, M.B., R.M.-P., A.K., P.D.; formal analysis, M.B., R.M.-P., A.K., P.D.; investigation, M.B., R.M.-P., A.K., P.D.; resources, M.B., R.M.-P., A.K., P.D.; data curation, M.B., R.M.-P., A.K., P.D.; writing—original draft preparation, M.B., R.M.-P., A.K., P.D.; writing—review and editing, M.B., R.M.-P., A.K., P.D.; visualization, M.B., R.M.-P., A.K., P.D.; supervision, M.B., R.M.-P., A.K., P.D.; project administration, M.B., R.M.-P., A.K., P.D.; funding acquisition, M.B., R.M.-P., A.K., P.D. All authors have read and agreed to the published version of the manuscript.

Funding: The article was funded by the University of Agriculture in Krakow.

Institutional Review Board Statement: Not applicable.

Informed Consent Statement: Not applicable.

Data Availability Statement: The survey in this study can be found at: https://docs.google.com/ forms/d/e/1FAIpQLSeDXCKAG8ISGP3D8WaMHeKswhCPFHho6TplAeaxBk0ZEWEIAg/viewform? fbclid=IwAR0zUz9Y9yKjpLar9nu0-GDSqeq8iddZHJPyJi1CQAa4DCfcsFxaMpXm3I4, accessed on 5 January 2021.

Conflicts of Interest: The authors declare no conflict of interest.

\section{References}

1. Rogall, H. Ekonomia Zrównoważonego Rozwoju. Teoria i Praktyka; Zysk i S-ka: Poznań, Poland, 2010; pp. 31-170.

2. Piontek, F.; Piontek, B. Alternatywne koncepcje wdrażania rozwoju i ich skutki dla kategorii kapitał. Nierówności Społeczne Wzrost Gospod. 2005, 6, 69-100.

3. Czyżowska, J.; Kłos, Z.; Seroka-Stolka, O. Świadomość ekologiczna elementem zrównoważonego rozwoju. In Perspektywy Zrównoważonego Rozwoju Przedsiębiorstw; Krawczyk-Sokołowska, I., Ed.; Wydział Zarządzania Politechniki Częstochowskiej: Częstochowa, Poland, 2012; pp. 9-15.

4. Godlewska, J. Edukacja dla zrównoważonego rozwoju. In Zrównoważony Rozwój-Aspekty Rozwoju Społeczności Lokalnych; Skup, M., Ed.; Fundacja Forum Inicjatyw Rozwojowych: Białystok, Poland, 2009; pp. 15-19.

5. EU Approach to Sustainable Development. Available online: https://ec.europa.eu/info/strategy/international-strategies/ sustainable-development-goals/eu-approach-sustainable-development_pl (accessed on 7 July 2021).

6. Communication from the Commission to the European Parliament, the Council, the European Economic and Social Committee and the Committee of the Regions. Next Steps For a Sustainable European Future, European Action for Sustainability. Available online: https:/ / eur-lex.europa.eu/legal-content/EN/TXT/HTML/?uri=CELEX:52016DC0739\&from=EN (accessed on 7 July 2021).

7. Zaman, A.U.; Lehmann, S. Challenges and Opportunities in Transforming a City into a "Zero Waste City". Challenges 2011, 2, 73-93. [CrossRef]

8. Wąsowicz, K.; Famielec, S.; Chełkowski, M. Gospodarka Odpadami Komunalnymi we Współczesnych Miastach; Fundacja Uniwersytetu Ekonomicznego w Krakowie: Kraków, Poland, 2018; pp. 15-16.

9. Song, Q.; Li, J.; Zeng, X. Minimizing the increasing solid waste through zero waste strategy. J. Clean. Prod. 2015, 104, 199-210. [CrossRef] 
10. Half a Tonne of Municipal Waste Generated per Person in the EU. Available online: https: / / ec.europa.eu/eurostat/en/web/ products-eurostat-news /- /ddn-20210216-1 (accessed on 1 July 2021).

11. OECD. Environment at a Glance 2015: OECD Indicators; OECD Publishing: Paris, France, 2015; p. 48. [CrossRef]

12. Kaza, S.; Yao, L.C.; Bhada-Tata, P.; Van Woerden, F. What a Waste 2.0: A Global Snapshot of Solid Waste Management to 2050. Urban Development; World Bank: Washington, DC, USA, 2018; p. 3. Available online: https://openknowledge.worldbank.org/handle/ 10986/30317 (accessed on 1 July 2021).

13. Zaman, A.U.; Lehmann, S. The zero waste index: A performance measurement tool for waste management systems in a "zero waste city". J. Clean. Prod. 2013, 50, 123-132. [CrossRef]

14. Mesjasz-Lech, A. Municipal Urban Waste Management-Challenges for Polish Cities in an Era of Circular Resource Management. Resources 2021, 10, 55. [CrossRef]

15. Dacko, M.; Dacko, A.; Mazur, G. Gospodarka odpadami a zrównoważony rozwój lokalny. Rocz. Nauk. SERiA 2018, 20, 34-40. [CrossRef]

16. Płachciak, A. Geneza idei rozwoju zrównoważonego. Ekonomia 2011, 5, 231-248.

17. Shi, L.; Han, L.; Yang, F.; Gao, L. The Evolution of Sustainable Development Theory: Types, Goals, and Research Prospects. Sustainability 2019, 11, 7158. [CrossRef]

18. Klarin, T. The Concept of Sustainable Development: From its Beginning to the Contemporary Issues. Zagreb Int. Rev. Econ. Bus. 2018, 21, 67-94. [CrossRef]

19. Lysenko, K. Zrównoważona gospodarka odpadami na przykładzie Rzeszowa. Studia Miej. 2004, 15, 31-41.

20. Shpak, N.; Kuzmin, O.; Melnyk, O.; Ruda, M.; Sroka, W. Implementation of a Circular Economy in Ukraine: The Context of European Integration. Resources 2020, 9, 96. [CrossRef]

21. Jakubiak, M. Wdrażanie strategii i wymogów Unii Europejskiej na przykładzie wprowadzania zrównoważonej gospodarki odpadami w Polsce. Zesz. Nauk./Pol. Tow. Ekon. 2014, 16, 33-44.

22. Zero Waste International Alliance. Available online: https:/ / zwia.org (accessed on 1 July 2021).

23. Zero Waste-Co to Jest? Available online: https:/ / www.jozefow.pl/zero-waste-co-to-jest-1488 (accessed on 1 July 2021).

24. Palmer, P. Faux Zero Waste Is Spreading. Available online: https://zerowasteinstitute.org/wp-content/uploads/2013/03/FauxZero-Waste.pdf (accessed on 2 July 2021).

25. Mauch, C. (Ed.) Introduction: The Call for Zero Waste. In A Future without Waste? Zero Waste in Theory and Practice; Rachel Carson Center for Environment and Society: Munich, Germany, 2016; pp. 5-11.

26. Zero Waste Definition. Available online: https:/ / zwia.org/zero-waste-definition/ (accessed on 2 July 2021).

27. Zaman, A.U. A Comprehensive Review of the Development of Zero Waste Management: Lessons Learned and Guidelines. J. Clean. Prod. 2015, 91, 12-25. [CrossRef]

28. Hannon, J.; Zaman, A.U. Exploring the Phenomenon of Zero Waste and Future Cities. Urban Sci. 2018, 2, 90. [CrossRef]

29. Cole, C.; Osmani, M.; Quddus, M.; Wheatley, A.; Kay, K. Towards a Zero Waste Strategy for an English Local Authority. Resour. Conserv. Recycl. 2014, 89, 64-75. [CrossRef]

30. Lorens, A. Ekonomia cyrkularna jako zrównoważony, odpowiedzialny proces wyrażony w architekturze i projektowaniu produktu cz.2. Builder 2021, 283, 37-39. [CrossRef]

31. Franco-García, M.-L.; Carpio-Aguilar, J.C.; Bressers, H. Towards Zero Waste, Circular Economy Boost, Waste to Resources. In Towards Zero Waste, Circular Economy Boost, Waste to Resources; Franco-García, M.-L., Carpio-Aguilar, J.C., Bressers, H., Eds.; Springer Nature: Cham, Switzerland, 2019; pp. 1-8.

32. Derej, W. Innowacje ekologiczne a rozwój Unii Europejskiej na przykładzie gospodarki odpadami komunalnymi. Studia Ekon. 2017, 324, 18-31.

33. Kozłowski, K. Ogromne Korzyści Płynące z Segregacji Odpadów. Available online: https://www.prawo.pl/biznes/ogromnekorzysci-plynace-z-segregacji-odpadow,160018.html (accessed on 5 July 2021).

34. Directive 75/442/EEC on Waste. Available online: https:/ / eur-lex.europa.eu/legal-content/EN/TXT/HTML/?uri=CELEX: 31975L0442\&from=EN (accessed on 1 July 2021).

35. Kosieradzka-Federczyk, A. Priorytety Unii Europejskiej w gospodarowaniu odpadami. Wspótczesne Probl. Zarządzania 2013, 1, 47-63.

36. Górski, M. Podstawowe Zasady Postepowania z Odpadami. Available online: http://www.zgora.pios.gov.pl/wp-content/ uploads/2014/03/Prof.-Marek-G\%C3\%B3rski-Gospodarowanie-odpadami.pdf (accessed on 3 July 2021).

37. Gov't Endorses the National Waste Management Plan up to 2030. Available online: https:/ /www.kmu.gov.ua/en/news/uryadshvaliv-nacplan-upravlinnya-vidhodami-do-2030-roku-gennadij-zubko (accessed on 5 July 2021).

38. Kidalov, S.; Vitiv, V.; Golovko, L.; Ladychenko, V. Legal Regulation of Waste Management in Ukraine on the Way to European Integration. Eur. J. Sustain. Dev. 2020, 9, 422-430. [CrossRef]

39. Deselnicu, D.C.; Militaru, G.; Deselnicu, V.; Zainescu, G.; Albu, L. Towards a circular economy-A Zero Waste programme for Europe. In Proceedings of the 7th International Conference on Advanced Materials and Systems ICAMS, Bucharest, Romania, 18-20 October 2018; pp. 563-568. [CrossRef]

40. Michniewska, K.; Grodkiewicz, P. Zero odpadów-Utopia czy rozwiązanie zbyt rozwiniętego konsumeryzmu? Logistyka Odzysku 2017, 2, 39-43. 
41. Mesjasz-Lech, A. Filozofia zero odpadów a strategie środowiskowe miast. Zesz. Nauk. Organ. Zarządzanie Politec. Ślaska 2018, $127,135-147$.

42. Nizar, M.; Munir, E.; Matseh, I.; Waller, V. The integrating of zero waste principles from national to local regulations: Case study of Banda Aceh, Indonesia. In IOP Conference Series: Earth and Environmental Science, Proceedings of the International Conference on Fisheries, Aquatic, and Environmental Sciences (ICFAES), Banda Aceh, Indonesia, 26-27 September 2018; IOP Publishing Ltd.: Bristol, UK, 2018. [CrossRef]

43. Musova, Z.; Musa, H.; Matiova, V. Environmentally Responsible Behaviour of Consumers: Evidence from Slovakia. Econ. Sociol. 2021, 14, 178-198. [CrossRef]

44. Yahya, W.K.; Musa, N.D.; Hashim, N.H. Understanding Environmentally Friendly Consumer Behavior. In Proceedings of the Regional Conference on Science, Technology and Social Sciences (RCSTSS), Pahang, Malaysia, 23-25 November 2014; Abdullah, M.A., Yahya, W.K., Ramli, N., Mohamed, S.R., Ahmad, B.E., Eds.; Springer: Berlin/Heidelberg, Germany, 2014. [CrossRef]

45. Roux, D.; Guiot, D. Measuring Second-Hand Shopping Motives, Antecedents and Consequences. Rech. Appl. Mark. 2008, 23, 63-94. [CrossRef]

46. Benefits of Zero Waste. Available online: https://www.torontoenvironment.org/zerowaste_benefits (accessed on 30 August 2021).

47. Nattagh, L. Reduce, Reuse, and Recycle Are Not Enough. Available online: https://www.w2rsolutions.com/post/5rs-hierarchy (accessed on 1 July 2021).

48. Globalne Zasady dla Społeczności Zero Waste. Available online: http:/ / www.otzo.most.org.pl/Zero_Waste_ZWIA.pdf (accessed on 5 July 2021).

49. Questionnaire Zero Waste. Available online: https://docs.google.com/forms/d/e/1FAIpQLSeDXCKAG81SGP3D8 WaMHeKswhCPFHho6TplAeaxBk0ZEWEIAg/viewform?fbclid=IwAR2mL0530GEvBeaDt5cb5w9rB1DGEFD2JDgW2X7 qV93DjlPqvF3gFCDxpLw (accessed on 15 January 2021).

50. Zarządzanie Odpadami w UE. Fakty i Liczby. Available online: https://www.europarl.europa.eu/news/pl/headlines/society/ 20180328STO00751/zarzadzanie-odpadami-w-ue-fakty-i-liczby-infografika (accessed on 22 June 2021).

51. Cohen, J. Statistical Power Analysis for the Behavioral Sciences, 2nd ed.; Lawrence Erlbaum Associates: Hillsdale, NJ, USA, 1988.

52. Stępien, M. Wybrane problemy zarządzania segregacją i recyklingiem odpadów komunalnych w Polsce. Zesz. Nauk. Politech. Częstochowskiej Zarzadzanie 2019, 33, 261-270. [CrossRef]

53. Wojewodzic, T. Priorytety w działalności inwestycyjnej gmin wiejskich województwa małopolskiego. Inżynieria Rol. 2003, 10, 147-154.

54. Satoła,Ł. Formy organizacyjno-prawne podmiotów wykonujących zadania z zakresu gospodarki komunalnej (na przykładzie województwa małopolskiego). Rocz. Nauk. SERiA 2016, 15, 247-253.

55. Zuzek, D.K. Świadomość ekologiczna przedsiębiorców jako element zrównoważonego rozwoju. Studia Ekon. 2017, 326, 162-171.

56. Balińska, A.; Jaska, E.; Werenowska, A. The Role of Eco-Apps in Encouraging Pro-Environmental Behavior of Young People Studying in Poland. Energies 2021, 14, 4946. [CrossRef]

57. Ochrona Środowiska Jako Problem Globalny. Available online: https://www.atmoterm.pl/ochrona-srodowiska-jako-problemglobalny / (accessed on 5 July 2021).

58. Special Eurobarometer Report: Attitudes of European Citizens Toward Environment, European Commission. March 2020. Available online: https: / europa.eu/eurobarometer/surveys/detail/2257 (accessed on 5 July 2021).

59. Płatkowska-Prokopczyk, L. The level of environmental awareness as a determinant of attitudes and behaviors developed by inhabitants of towns and villages-A comparative case study. Infrastruct. Ecol. Rural Areas 2017, IV, 1633-1647. [CrossRef]

60. Rejman, K.; Kowrygo, B.; Laskowski, W. Ocena struktury spożycia żywności w Polsce w aspekcie wymogów zrównoważonej konsumpcji. J. Agribus. Rural Dev. 2015, 3, 503-512.

61. Nycz-Wróbel, J. Zachowania ekologiczne w gospodarstwach domowych (na przykładzie opinii mieszkańców woj. podkarpackiego). Zarzadzanie Mark. 2012, 19, 39-50. [CrossRef]

62. Sadowy, K. Odpady jako miara niezrównoważonej konsumpcji. Studia Prace Kol. Zarzadzania Finans. SGH 2014, 138 , 39-53.

63. Smolnik, P. Istota i znaczenie gospodarki odpadami komunalnymi. Zesz. Nauk. Politech. Częstochowskiej Zarzadzanie 2013, 10, 69-75.

64. Jednotematyczne Badanie Świadomości i Zachowań Ekologicznych Mieszkańców Polski. Butelki Zwrotne. Opracowane dla Ministerstwa Środowiska przez DANAE sp. z o.o. Available online: https://www.gov.pl/web/klimat/badania-swiadomosciekologicznej (accessed on 22 June 2021).

65. Dąbrowski, A. Ekonomia odpowiedzialności. In Kultura (Nie)odpowiedzialności; Bogunia-Borowska, M., Ed.; Wydawnictwo Naukowe PWN: Warszawa, Poland, 2021; pp. 217-230.

66. What Is the Zero Waste Lifestyle? Available online: https:/ / www.centerforecotechnology.org/zero-waste-lifestyle (accessed on 1 July 2021).

67. Connett, P. Zero Waste wins: It's not just better for the environment, it's better for the local economy. Ask Nova Scotia. Altern. J. 2006, 32, 14-16.

68. Watson, S.; Smith, E.E. Assessing Customer Attitudes towards Zero Waste Shopping. J. Mgt. Mkt. Rev. 2020, 5, 244-250. [CrossRef]

69. Saplacan, Z.; Marton, B. Determinants of Adopting a Zero Waste Consumer Lifestyle. Reg. Bus. Stud. 2019, 11, 25-39. [CrossRef]

70. Zaman, A.U. A Strategic Framework for Working toward Zero Waste Societies Based on Perceptions Surveys. Recycling 2017, 2, 1. [CrossRef] 
71. Zero Waste i Recykling. Available online: https://gethome.pl/blog/zero-waste-i-recykling/ (accessed on 5 July 2021).

72. Global Consumer Insights Survey 2020. Available online: https://www.pwc.pl/pl/publikacje/transformacja-konsumentazmiana-zachowan-i-decyzji-zakupowych.html (accessed on 12 July 2021).

73. Packaging Free Shops in Europe an Initial Report, Consumption \& Production. 2020. Available online: https://www.eunomia.co. uk/reports-tools/packaging-free-shops-in-europe/ (accessed on 12 July 2021).

74. Tseng, M.-L.; Lim, M.K.; Ali, M.H.; Christianti, G.; Juladacha, P. Assessing the sustainable food system in Thailand under uncertainties: Governance, distribution and storage drive technological innovation. J. Ind. Prod. Eng. 2021, 1-8. [CrossRef]

75. Tseng, M.-L.; Tran, T.P.T.; Ha, H.M.; Bui, T.-D.; Lim, M.K. Sustainable industrial and operation engineering trends and challenges Toward Industry 4.0: A data driven analysis. J. Ind. Prod. Eng. 2021, 1-18. [CrossRef]

76. Dacko, M.; Płonka, A. Sustainable local development through the search for and implementation of good practices in waste management. In Proceedings of the Economic Science for Rural Development Conference, LLU ESAF, Jelgava, Latvia, 9-10 May 2019; pp. 77-83. [CrossRef]

77. Kastrau, E.; Sosnowska-Noworól, R.; Woźniak, Z. Ekonomiczny, ekologiczny i społeczny aspekt odzysku odpadów komunalnych na przykładzie legnickiego przedsiębiorstwa gospodarki komunalnej spółka z o.o. Prace Nauk. Uniw. Ekon. Wrocławiu 2015, 377, 190-202. [CrossRef]

78. Municipal Waste Treatment 2019. Available online: https://www.cewep.eu/municipal-waste-treatment-2019/ (accessed on 12 July 2021).

79. Ukrainian National Waste Management Strategy. 15 January 2021. Available online: https://dlf.ua/en/ukrainian-nationalwaste-management-strategy-until-2030-approved/\#1 (accessed on 12 July 2021).

80. Papagiannis, F.; Gazzola, P.; Burak, O.; Pokutsa, I. A European Household Waste Management Approach: Intelligently Clean Ukraine. J. Environ. Manag. 2021, 294, 113015. [CrossRef]

81. Tit, D.M.; Bungau, S.; Cseppento, C.N.; Copolovici, D.M.; Buhas, C. Disposal of unused medicines resulting from home treatment in Romania. J. Environ. Prot. Ecol. 2016, 17, 1425-1433.

82. Bungau, S.; Tit, D.M.; Fodor, K.; Cioca, G.; Agop, M.; Iovan, C.; Cseppento, D.C.N.; Bumbu, A.; Bustea, C. Aspects Regarding the Pharmaceutical Waste Management in Romania. Sustainability 2018, 10, 2788. [CrossRef] 